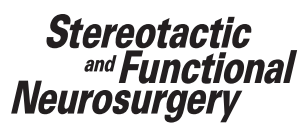

Stereotactic

Neurosurgery
Stereotact Funct Neurosurg 2011;89:83-88

DOI: $\underline{10.1159 / 000323338}$
Received: September 2, 2010

Accepted after revision: November 28, 2010

Published online: February 2, 2011

\title{
Motor Cortex Stimulation for Trigeminal Neuropathic or Deafferentation Pain: An Institutional Case Series Experience
}

\author{
Ahmed M. Raslan Morad Nasseri Diaa Bahgat Emun Abdu Kim J. Burchiel \\ Department of Neurological Surgery, Oregon Health \& Science University, Portland, Oreg., USA
}

\section{Key Words}

Motor cortex stimulation - Trigeminal neuropathy •

Trigeminal neuropathic pain - Trigeminal deafferentation pain

\begin{abstract}
Background: Trigeminal neuropathy is a rare, devastating condition that can be intractable and resistant to treatment. When medical treatment fails, invasive options are limited. Motor cortex stimulation (MCS) is a relatively recent technique introduced to treat central neuropathic pain. The use of MCS to treat trigeminal neuropathic or deafferentation pain is not widespread and clinical data in the medical literature that demonstrate efficacy are limited. Method: We retrospectively reviewed patients with trigeminal neuropathic or trigeminal deafferentation pain who were treated at the Oregon Health \& Science University between 2001 and 2008 by 1 neurosurgeon using MCS. Results: Eight of 11 patients (3 male, 8 female) underwent successful permanent implantation of an MCS system. All 8 patients reported initial satisfactory pain control. Three failed to experience continued pain control (6 months of follow-up). Five continued to experience long-term pain control (mean follow-up, 33 months). Average programming sessions were 2.2/year (all 8 patients) and 1.55/year (5 patients who sustained long-term
\end{abstract}

pain control). Patients with anesthesia dolorosa or trigeminal deafferentation pain who had previously undergone ablative trigeminal procedures responded poorly to MCS. We encountered no perioperative complications. Conclusion: MCS is a safe and potentially effective therapy in certain patients with trigeminal neuropathy.

Copyright $\odot 2011$ S. Karger AG, Basel

\section{Introduction}

Trigeminal neuropathy is characterized by constant, severe pain, as well as sensory deficits in the distribution of the trigeminal nerve, which are related to disease of, or injury to, the trigeminal nerve or ganglion. According to Burchiel's [1] previous facial pain classification, trigeminal neuropathy can result from unintentional injury to the trigeminal system, e.g. from facial trauma, oral surgery, ear, nose and throat surgery, root injury from posterior fossa or skull base surgery, stroke, and rarely idiopathic trigeminal neuropathy, and is classified as trigeminal neuropathic pain (TNP), or it can result from intentional injury to the trigeminal system, e.g. from neurectomy, gangliolysis, rhizotomy, nucleotomy, tractotomy or other denervating procedures and is classified as trigeminal deafferentation pain (TDP) [1].

\section{KARGER}

Fax +41613061234 E-Mail karger@karger.ch www.karger.com
(C) 2011 S. Karger AG, Basel

$1011-6125 / 11 / 0892-0083 \$ 38.00 / 0$

Accessible online at:

www.karger.com/sfn
Kim J. Burchiel, MD, FACS

Neurological Surgery, CH8N, Oregon Health \& Science University

3303 SW Bond Ave

Portland, OR 97239 (USA)

Tel. +1 503494 4314, Fax +1 503346 6810,E-Mail burchiek@ ohsu.edu 
Despite extensive studies, pharmacological treatment of TNP or TDP remains limited to prescription of anticonvulsant and antidepressant drugs, which have demonstrated minimal therapeutic benefit. When surgical treatment of trigeminal neuralgia fails, some patients will suffer TDP for which there are few, if any, effective treatments [2]. Ablative treatments that are effective for trigeminal neuralgia, such as radiofrequency gangliolysis, glycerol rhizotomy, balloon compression or gamma knife rhizolysis, can, in fact, all lead to TDP. Deep brain stimulation of the sensory thalamus and periaqueductal or periventricular gray matter with stereotactic placement of electrodes has not proven to be efficacious for TNP or TDP [3].

Motor cortex stimulation (MCS) was first performed by Tsubokawa et al. [4] to treat central pain and showed promising results. The potential benefits of MCS used to treat peripheral and central neuropathic pain have been described [5]; however, there remains much to be investigated about the potential benefits of MCS technology with regard to TNP or TDP syndromes. Few investigators have examined the potential role of MCS as a strategy to treat TNP or TDP, and of those, most have reported relatively short follow-up results $[3,6-8]$.

In this study, our aim was to examine the natural history of, and report our institutional experience with, MCS for treatment of TNP and TDP syndromes. Primarily, we examined the longevity of satisfactory pain control following MCS used to treat TNP and TDP, pain control outcome, initial response to trial stimulation, specific features of nonresponders and procedural complications.

\section{Methods}

\section{Data Analysis}

A retrospective case series review was undertaken, between January 2001 and December 2008, of patients who underwent surgical management of TNP or TDP at the Oregon Health \& Science University by the senior author (K.J.B.) using MCS. The study was approved by the Oregon Health \& Science University Institutional Review Board.

Patient data were collected for analysis and included demographics, clinical presentation, operative details including motor threshold and initial stimulation parameters, perioperative complications (if any), first follow-up pain control outcome, last follow-up pain control outcome, number of programming sessions, pain control longevity, and MCS system longevity and outcome.

Pain outcome after surgery was assessed by a 4-level scale; level 1: complete pain control, level 2: satisfactory pain control ( $>50 \%$ pain relief), level 3: same pain level as before the procedure, and level 4: worse pain compared to initial presentation.
Pain control longevity, measured in months, was determined from a patient perspective; the periods of time with inadequate pain control prior to reprogramming were added and the total value subtracted from the total lifetime of the stimulator. The number of programming sessions for each individual was divided by the longevity of the stimulator to determine a session/year number for each subject, and then the mean number of sessions/ year was reported for the entire cohort and for subgroups within the cohort. Data are reported as means \pm standard deviation.

\section{Surgical Technique}

All patients underwent placement of 4 -contact $\left(\right.$ Resume ${ }^{\circledR}$, Medtronic, Inc., Minn., USA) or 8-contact (Specify ${ }^{\circledR}$, Medtronic, Inc.) paddle electrodes in the epidural space overlying the motor cortex under general anesthesia without muscular blockade. Prior to the procedure, stereotactic magnetic resonance imaging was obtained to allow for intraoperative StealthStation navigation (Medtronic, Inc.). A 3-dimensional cortical model was reconstructed on the Stealth machine and the location of the central sulcus and facial eminence determined (fig. 1). Preoperative antibiotics and steroids were administered. After general anesthesia was induced, a Mayfield skull clamp was applied to the patient's head using an ample amount of local anesthetic in anticipation of lightening anesthesia to determine the motor threshold for seizure induction. The patient was kept supine and the head tilted with the aid of a shoulder roll. A linear incision was made overlying the central sulcus after infiltration with anesthetics. Then a craniotomy centered over the central sulcus in the region of the facial eminence was made. The craniotomy was performed to accommodate for the size of a paddle electrode and to allow somatosensory evoked potential recording from the sensory cortex utilizing the electrode itself. Somatosensory evoked potential study with detection of N20-P20 phase reversal to identify the central sulcus was undertaken and the orientation of the motor cortex determined using navigation. The electrode was then placed along the orientation of the motor strip centered over the region of the facial eminence.

The electrode was then secured to the dura mater using 4-0 silk sutures. Next, the bone flap was replaced and secured with titanium plates. Extension cables were attached to the electrode and then tunneled through the skin for an external stimulator connection. Anesthesia was then lightened and patient communication established. Stimulation of the motor cortex was then achieved by connecting the electrode to an Ojemann cortical stimulator. Terrains of $1-\mathrm{ms}$ pulse width and $50-\mathrm{Hz}$ frequency were applied in an incremental fashion until facial twitches were encountered. This minimal amplitude at which twitches were encountered constitutes the motor threshold, which was considered when setting the maximum possible amplitude of stimulation in the postoperative period.

Once the threshold was established, anesthesia was deepened and closure completed. A postoperative computed tomography scan was performed for all patients. The patient was allowed to try the stimulation for up to 2 weeks while in the inpatient setting. Different combinations of stimulations were usually attempted with a goal of achieving a target pain reduction of $50 \%$ on the pain numerical rating scale. Initial stimulation parameters were as follows: amplitude 2-5 V, pulse width $120-450 \mathrm{~ms}$, and frequency $30-50 \mathrm{~Hz}$. When a reduction in facial pain of $\geq 50 \%$ compared to initial presentation is achieved, the patient underwent surgery for 


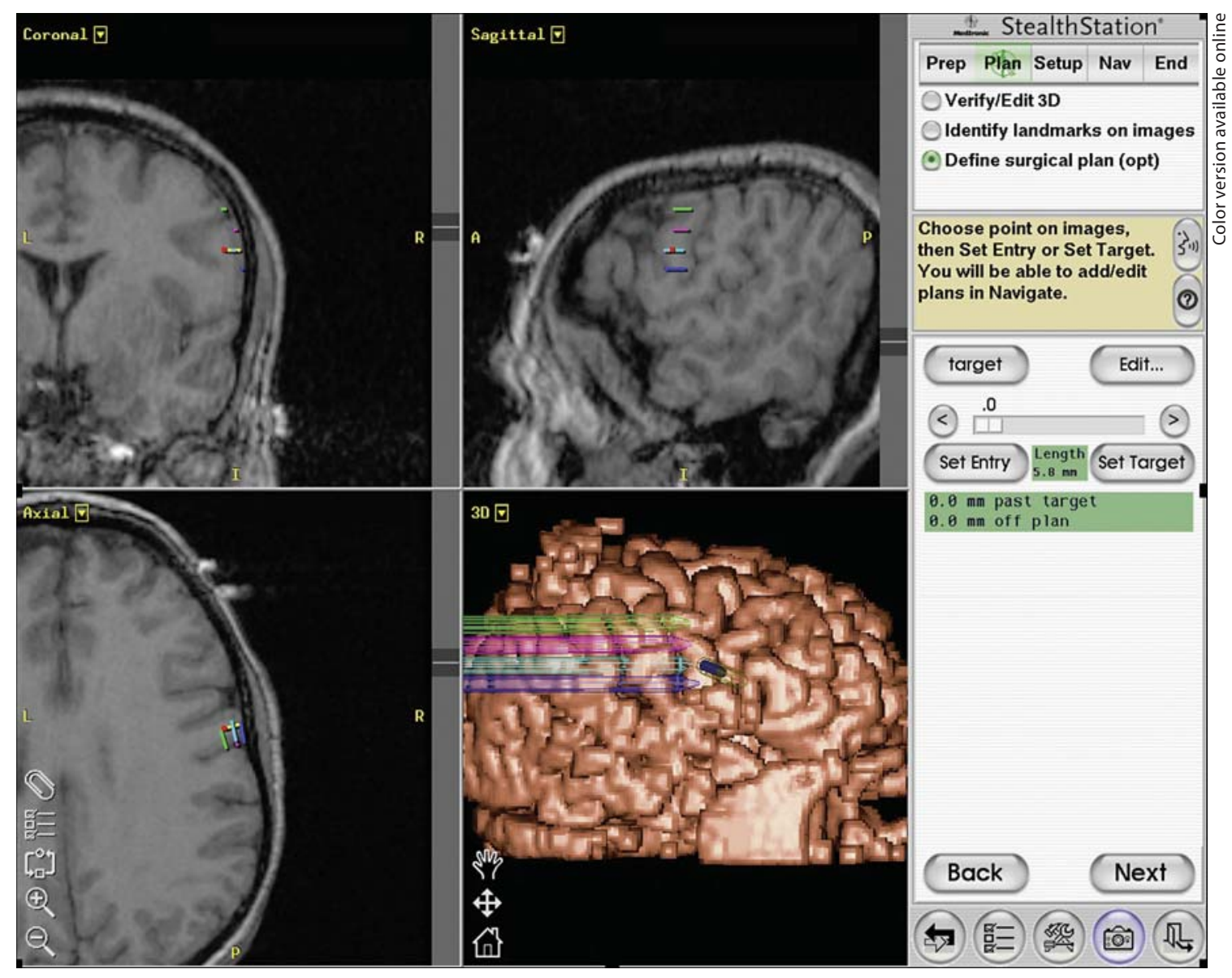

Fig. 1. A StealthStation navigation graphic user interface screen shot. The right lower quadrant shows a 3-dimensional reconstructed cortical surface of the localization of the central sulcus and facial eminence. Colored markings represent points where stimulation induced facial twitches and thus an ideal implantation location (for colors, see online version).

permanent implantation of an internal pulse generator $\left(\right.$ Soletra ${ }^{\circledR}$, Synergy ${ }^{\circledR}$, Medtronic, Inc.); however, if pain reduction was less than $50 \%$, the trial was deemed a failure and the electrode was removed without placement of a permanent stimulator.

\section{Results}

Eleven patients ( 3 male, 8 female) underwent implantation of MCS electrodes for TNP or TDP. Mean patient age was 47.3 years (range, $31-76$ years). Of the TNP patients, 3 had a prior dental procedure, 1 was the result of a previous facial trauma, 1 was due to trigeminal neuropathy following sinus surgery for Sluder's neuralgia, 1 was due to Wallenberg syndrome, 1 was the result of a previous sinus surgery, and 1 was due to idiopathic trigeminal neuropathy. Of the TDP patients, 2 had prior mi- crovascular decompression (MVD) procedures for type 2 trigeminal neuralgia [1] and 1 had anesthesia dolorosa due to multiple interventions for prior trigeminal neuralgia that included a radiofrequency rhizotomy and MVD procedure (table 1). Mean pain duration prior to the procedure was 4.5 years (range, 1-12 years). Of the 11 patients who underwent MCS electrode placement, 8 (72\%) patients experienced successful trials (a reduction in facial pain of $\geq 50 \%$ compared to initial presentation) and proceeded with placement of a permanent neurostimulator. The 3 patients who had unsatisfactory pain control (a reduction in facial pain of $<50 \%$ ) comprised 2 patients with TDP (1 patient with anesthesia dolorosa, 1 patient with prior MVD for trigeminal neuralgia, that was classified as trigeminal neuralgia type 2 [1]), and 1 patient with TNP (idiopathic TNP). 
Table 1. Neuropathic facial pain patient demographics, disease etiology, MCS trial response, and pain control and MCS longevity

\begin{tabular}{|c|c|c|c|c|c|c|c|c|c|c|}
\hline $\begin{array}{l}\text { Age } \\
\text { years }\end{array}$ & $\begin{array}{l}\text { Gen- } \\
\text { der }\end{array}$ & Etiology & $\begin{array}{l}\text { Pain } \\
\text { dura- } \\
\text { tion } \\
\text { years }\end{array}$ & Response to MCS trial & $\begin{array}{l}\text { Stimulator } \\
\text { parameters }\end{array}$ & $\begin{array}{l}\text { Outcome at } \\
\text { first follow-up } \\
\text { ( } 2 \text { weeks) }\end{array}$ & $\begin{array}{l}\text { Outcome at last } \\
\text { follow-up }\end{array}$ & MCS outcome & $\begin{array}{l}\text { Repro- } \\
\text { gram- } \\
\text { ming ses- } \\
\text { sions, } \mathrm{n}\end{array}$ & $\begin{array}{l}\text { Pain control } \\
\text { longevity/ } \\
\text { MCS longev- } \\
\text { ity, months }\end{array}$ \\
\hline 36 & M & Facial trauma & 1 & $\begin{array}{l}>50 \% \text { pain control, } \\
\text { stimulator implanted }\end{array}$ & $\begin{array}{l}3 \mathrm{~V}, 240 \mathrm{~ms}, \\
50 \mathrm{~Hz}\end{array}$ & $\begin{array}{l}\text { Complete } \\
\text { pain control }\end{array}$ & $\begin{array}{l}\text { Complete pain } \\
\text { control ( } 6 \text { months) }\end{array}$ & $\begin{array}{l}\text { Stimulator } \\
\text { maintained as of } \\
\text { last follow-up }\end{array}$ & 1 & $6 / 6$ \\
\hline 37 & $\mathrm{~F}$ & $\begin{array}{l}\text { Sluder's } \\
\text { neuralgia after } \\
\text { sinus surgery }\end{array}$ & 5 & $\begin{array}{l}>50 \% \text { pain control, } \\
\text { stimulator implanted }\end{array}$ & $\begin{array}{l}3 \mathrm{~V}, 250 \mathrm{~ms}, \\
30 \mathrm{~Hz}\end{array}$ & $\begin{array}{l}\text { Complete } \\
\text { pain control }\end{array}$ & $\begin{array}{l}\text { Satisfactory pain } \\
\text { control ( } 28 \text { months })\end{array}$ & $\begin{array}{l}\text { Stimulator } \\
\text { maintained }\end{array}$ & 3 & $26 / 28$ \\
\hline 47 & $\mathrm{~F}$ & $\begin{array}{l}\text { Following } \\
\text { dental } \\
\text { procedure }\end{array}$ & 3 & $\begin{array}{l}>50 \% \text { pain control, } \\
\text { stimulator implanted }\end{array}$ & $\begin{array}{l}3.5 \mathrm{~V}, 120 \\
\mathrm{~ms}, 30 \mathrm{~Hz}\end{array}$ & $\begin{array}{l}\text { Satisfactory } \\
\text { pain control }\end{array}$ & $\begin{array}{l}\text { Satisfactory pain } \\
\text { control ( } 72 \text { months) }\end{array}$ & $\begin{array}{l}\text { Stimulator } \\
\text { maintained } \\
\text { (replaced once) }\end{array}$ & 9 & $64 / 72$ \\
\hline 53 & $\mathrm{M}$ & $\begin{array}{l}\text { Wallenberg } \\
\text { syndrome }\end{array}$ & 1 & $\begin{array}{l}>50 \% \text { pain control, } \\
\text { stimulator implanted }\end{array}$ & $\begin{array}{l}3 \mathrm{~V}, 240 \mathrm{~ms}, \\
50 \mathrm{~Hz}\end{array}$ & $\begin{array}{l}\text { Satisfactory } \\
\text { pain control }\end{array}$ & $\begin{array}{l}\text { Complete pain } \\
\text { control ( } 38 \text { months) }\end{array}$ & $\begin{array}{l}\text { Stimulator } \\
\text { maintained as of } \\
\text { last follow-up } \\
\text { (replaced once) }\end{array}$ & 5 & $34 / 38$ \\
\hline 40 & $\mathrm{~F}$ & $\begin{array}{l}\text { Following sinus } \\
\text { surgery }\end{array}$ & 12 & $\begin{array}{l}>50 \% \text { pain control, } \\
\text { stimulator implanted }\end{array}$ & $\begin{array}{l}5 \mathrm{~V}, 180 \mathrm{~ms}, \\
50 \mathrm{~Hz}\end{array}$ & $\begin{array}{l}\text { Satisfactory } \\
\text { pain control }\end{array}$ & $\begin{array}{l}\text { Satisfactory pain } \\
\text { control ( } 42 \text { months) }\end{array}$ & $\begin{array}{l}\text { Stimulator } \\
\text { maintained as of } \\
\text { last follow-up } \\
\text { (replaced twice) }\end{array}$ & 5 & $38 / 42$ \\
\hline 38 & $\mathrm{~F}$ & $\begin{array}{l}\text { Following } \\
\text { dental } \\
\text { procedure }\end{array}$ & 6 & $\begin{array}{l}>50 \% \text { pain control, } \\
\text { stimulator implanted }\end{array}$ & $\begin{array}{l}2 \mathrm{~V}, 240 \mathrm{~ms}, \\
30 \mathrm{~Hz}\end{array}$ & $\begin{array}{l}\text { Pain } \\
\text { unchanged }\end{array}$ & $\begin{array}{l}\text { Unsatisfactory pain } \\
\text { control ( } 3 \text { years) }\end{array}$ & $\begin{array}{l}\text { Stimulator } \\
\text { removed at } 3 \text { years }\end{array}$ & 2 & $3 / 36$ \\
\hline 57 & $\mathrm{~F}$ & $\begin{array}{l}\text { Following } \\
\text { dental } \\
\text { procedure }\end{array}$ & 1 & $\begin{array}{l}>50 \% \text { pain control, } \\
\text { stimulator implanted }\end{array}$ & $\begin{array}{l}3 \mathrm{~V}, 450 \mathrm{~ms}, \\
50 \mathrm{~Hz}\end{array}$ & $\begin{array}{l}\text { Complete } \\
\text { pain control }\end{array}$ & $\begin{array}{l}\text { Unsatisfactory pain } \\
\text { control ( } 6.5 \text { months) } \\
\text { discomfort noted at } \\
\text { generator site }\end{array}$ & $\begin{array}{l}\text { Stimulator } \\
\text { removed } \\
\text { ( } 7 \text { months of } \\
\text { follow-up) }\end{array}$ & 4 & $4 / 7$ \\
\hline 31 & $\mathrm{~F}$ & $\begin{array}{l}\text { Trigeminal } \\
\text { neuralgia type } 2 \\
\text { after MVD }\end{array}$ & 5 & $\begin{array}{l}>50 \% \text { pain control, } \\
\text { stimulator implanted }\end{array}$ & $\begin{array}{l}3 \mathrm{~V}, 450 \mathrm{~ms}, \\
50 \mathrm{~Hz}\end{array}$ & $\begin{array}{l}\text { Satisfactory } \\
\text { pain control } \\
\text { ( } 4 \text { weeks' } \\
\text { follow-up) }\end{array}$ & $\begin{array}{l}\text { Unsatisfactory pain } \\
\text { relief ( } 23 \text { months) }\end{array}$ & $\begin{array}{l}\text { Stimulator } \\
\text { removed at } \\
\text { another institution } \\
\text { at } 24 \text { months }\end{array}$ & 5 & $6 / 24$ \\
\hline 76 & $\mathrm{~F}$ & $\begin{array}{l}\text { Anesthesia } \\
\text { dolorosa } \\
\text { after MVD and } \\
\text { radiofrequency } \\
\text { gangliolysis }\end{array}$ & 4 & $\begin{array}{l}<50 \% \text { pain control, } \\
\text { failed trial - } \\
\text { no implantation }\end{array}$ & N/A & N/A & $\mathrm{N} / \mathrm{A}$ & N/A & N/A & N/A \\
\hline 49 & $\mathrm{~F}$ & $\begin{array}{l}\text { Trigeminal } \\
\text { neuralgia type } 2 \\
\text { after MVD, and } \\
\text { following gam- } \\
\text { ma knife sur- } \\
\text { gery for trigem- } \\
\text { inal neuralgia }\end{array}$ & 7 & $\begin{array}{l}<50 \% \text { pain control, } \\
\text { failed trial - } \\
\text { no implantation }\end{array}$ & N/A & N/A & N/A & N/A & N/A & N/A \\
\hline 57 & M & Idiopathic & 7 & $\begin{array}{l}<50 \% \text { pain control, } \\
\text { failed trial - } \\
\text { no implantation }\end{array}$ & $\mathrm{N} / \mathrm{A}$ & N/A & $\mathrm{N} / \mathrm{A}$ & N/A & N/A & N/A \\
\hline
\end{tabular}


Of the 8 patients who underwent the full system implantation, 3 reported complete pain relief (level 1 pain control), 4 reported satisfactory pain relief (level 2 pain control), and 1 experienced no pain relief (level 2 pain control), all at the 2-week postoperative visit.

Five of $8(62.5 \%)$ patients (group A) continued to experience adequate pain relief (level 1 and level 2 pain control) at the time of their last documented follow-up visit (the shortest being 6 months after implantation). Three of 8 (37.5\%) patients (group B) discontinued stimulator use due to unsatisfactory pain relief (level 3 pain control) and subsequently had the stimulator removed after implantation at 7, 24, and 36 months. In 1 case, a patient reported at the last follow-up that the stimulator had provided adequate pain control for only 3 months of the total 36 months that the stimulator was in place.

The mean MCS system and pain control longevity for the entire cohort were $30.1 \pm 22$ months (range, 6-72 months) and $22.6 \pm 21.9$ months (range, 3-64 months), respectively. In group A, the mean MCS system and pain control longevity were $37.2 \pm 24$ months (range, 6-72 months), and $33.6 \pm 21$ months (range, 6-64 months), respectively. In group B, the mean MCS system and pain control longevity were $22.3 \pm 14.5$ months (range, 7-36 months) and $4.3 \pm 1.5$ months (range, 3-6 months), respectively.

The mean number of programming sessions/year for the entire cohort was 2.2. The mean number for group A and group B was 1.55 and 3.3 sessions/year, respectively. There were no perioperative complications related to the placement of the MCS device in our study cohort.

\section{Discussion}

Penfield and Jasper [9] first noted the involvement of the motor cortex in sensory phenomena when they reported a sensory response after stimulation of the precentral gyrus during an epilepsy surgery (the adjacent postcentral gyrus having previously been resected in this particular patient). Tsubokawa et al. [4] were the first to introduce MCS for treatment of central and neuropathic pain syndromes. Meyerson et al. [7] published the first use of MCS for the treatment of TNP or TDP, reporting that 5 of 12 patients had complete pain relief and 8 of 12 patients had some degree of pain relief 1 year after surgery. In 1996, Ebel et al. [6] screened 7 patients with MCS electrode implantation; 6 underwent a permanent MCS system implantation, 5 initially experienced $>80 \%$ pain relief, of which 2 reportedly lost the beneficial effect over the ensuing months. In 1999, Nguyen et al. [8] reported a larger series of patients who underwent MCS for central pain, that included 11 patients with TNP or TDP, all of whom experienced $40-100 \%$ pain relief; the follow-up duration was, however, relatively short. The most recent series of MCS for TNP or TDP was reported by Brown and Pilitsis [3] who conducted a prospective study that screened 10 patients; 8 underwent permanent implantation, 6 of whom reported sustained pain relief at followup (range, 3-24 months). The results we present are similar to those of Ebel et al. [6], whereby 8 of 11 patients passed initial screening and underwent permanent implantation and 5 of the 8 reported long-lasting pain relief after an initial period of success. Varying diagnostic nomenclature, such as central facial pain, neuropathic facial pain, or TNP, is used in most of the previous reports that detail the use of MCS for trigeminal neuropathy; however, despite the variability and based on Burchiel's classification of facial pain [1], patients can all be described as having TNP or TDP.

Durability of MCS therapy use to treat TNP and TDP is a critical concern. The purpose of this study was to provide some insight into the expected longevity of the painrelieving effect of MCS in association with TNP or TDP. Our main findings indicate that despite seemingly appropriate candidacy, 3 of 11 patients failed initial screening placement and of the 8 patients who underwent permanent implantation of the MCS generator, 2 discontinued therapy in the first 6 months after implantation and the third had the stimulator removed after 3 years (all 3 patients reported adequate pain control for 6 months or less). Five of 8 patients (group A) who underwent permanent implantation of the MCS generator maintained treatment until the last documented follow-up, which included 1 patient with a follow-up of 6 months. Nevertheless, in group A, the mean MCS system longevity and pain control longevity were 37.2 and 33.6 months, respectively. With caution, one could infer that if a patient maintains adequate pain relief for more than 6 months following MCS implantation, the beneficial effect is sustainable.

Patients who have undergone permanent implantation of an MCS generator require multiple reprogramming sessions, the number of which is directly proportional to treatment durability. The mean number of programming sessions/year for the entire cohort was 2.2. The mean number for groups A and B were 1.55 and 3.3 sessions/ year, respectively. The higher average number of sessions per year for those who failed MCS therapy (group B) reflects more attempts to capture successful stimulation in 
this particular subgroup and a shorter duration of longevity compared with group A who experienced longer longevity overall.

Two of the 3 patients who failed the initial MCS electrode placement screening had TDP and 1 had idiopathic trigeminal neuropathy. Furthermore, 1 patient in group $\mathrm{B}$ (those who did not experience long-lasting pain relief) of our study also had TDP. In fact, all patients with TDP either failed the stimulation trial or subsequently failed permanent stimulation. Based on these limited observations, one could infer that TDP is resistant to MCS treatment.

In this case series, we demonstrate the difference between longevity of the MCS system and durability of pain relief. As we have indicated, 1 patient who clearly lost all beneficial MCS device effects within the first 3 months after treatment continued to harbor the device for 3 years before deciding to have it removed. Patients experienced periods of unsatisfactory pain relief within a broader duration of acceptable or satisfactory pain control, the most common example being the time period between loss of the MCS pain control effect and regaining pain control by reprogramming. While the difference between pain control longevity and MCS device longevity was crudely quantified in our current study, the notion of measuring the duration of improved pain control within the lifetime of a stimulator or neuromodulation device is a critical concept that indicates efficacy and should be further investigated.

Our institutional experience has not included any subdural electrode placements to date. We have also not encountered a situation where stimulation success was dependent on stimulation amplitude to the point of needing to increase amplitude beyond predetermined settings. Failures usually occur regardless of the stimulation amplitude and there is a ceiling as to how high stimulation can be elevated; 'motor' or 'seizure' threshold (approx. $8-10 \mathrm{~V}$ ) delivered epidurally.

We are aware of the arbitrary nature of the 2-week trial duration and whether or not it might be considered too short to unequivocally deem a trial negative. However, extending a trial beyond 2 weeks would elevate the risk of infection after implantation. Given that most patients failed within the first 6 months of implantation, an alternate strategy would be to implant all candidates and consider the first 6 months a trial period; however, this strategy would come with increased costs.

We attempted to focus on pain control, initial response to trial stimulation, longevity of pain control, specific features of nonresponders and procedural complications. In conclusion, our case series suggests that MCS is a reasonable treatment option for patients with TNP. Once the MCS was implanted if passing the initial screening electrode trial, $62.5 \%$ of patients experienced satisfactory pain relief for an average of 33 months. Our results suggest that potential failure of MCS to control TNP or TDP will be evident within the first 6 months of implantation with TDP seemingly less responsive to MCS than TNP. MCS is safe and appears to be well tolerated by patients.

\section{Acknowledgement}

We would like to thank Shirley McCartney, $\mathrm{PhD}$, for editorial assistance.

\section{References}

Burchiel KJ: A new classification for facial pain. Neurosurgery 2003;53:1164-1167.

-2 Henderson JM, Lad SP: Motor cortex stimulation and neuropathic facial pain. Neurosurg Focus 2006;21:E6.

-3 Brown JA, Pilitsis JG: Motor cortex stimulation for central and neuropathic facial pain: a prospective study of 10 patients and observations of enhanced sensory and motor function during stimulation. Neurosurgery 2005;56:290-297.

-4 Tsubokawa T, Katayama Y, Yamamoto T, Hirayama T, Koyama S: Chronic motor cortex stimulation for the treatment of central pain. Acta Neurochir Suppl 1991;52:137-139.

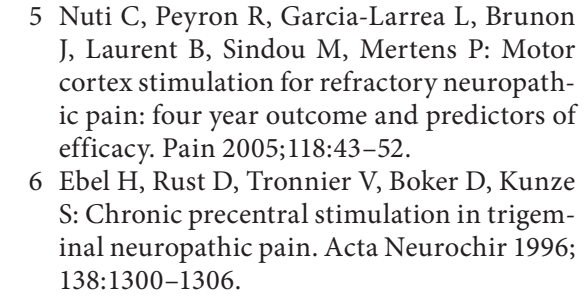

Nuti C, Peyron R, Garcia-Larrea L, Brunon J, Laurent B, Sindou M, Mertens P: Motor cortex stimulation for refractory neuropathic pain: four year outcome and predictors of efficacy. Pain 2005;118:43-52.

$S$ : Chronic precentral stimulation in trigem 138:1300-1306.
Meyerson BA, Lindblom U, Linderoth B, Lind G, Herregodts P: Motor cortex stimulation as treatment of trigeminal neuropathic pain. Acta Neurochir Suppl 1993;58:150-153.

8 Nguyen JP, Lefaucheur JP, Decq P, Uchiyama T, Carpentier A, Fontaine D, Brugieres P, Pollin B, Feve A, Rostaing S, Cesaro P, Keravel Y: Chronic motor cortex stimulation in the treatment of central and neuropathic pain. Correlations between clinical, electrophysiological and anatomical data. Pain 1999;82:245-251.

9 Penfield W, Jasper H (eds): Epilepsy and the Functional Anatomy of the Human Brain. Boston, Brown and Company, 1954. 